\title{
PROFIL PROFESIONALISME DOSEN JURUSAN PENDIDIKAN BAHASA INGGRIS
}

\author{
Ni Made Ratminingsih \\ Universitas Pendidikan Ganesha, Jl. Udayana 11 Singaraja \\ e-mail: made_ratminingsih@yahoo.com.au
}

\begin{abstract}
The Profile of Lecturers' Professionalism of English Education Department. The aim of this research was to describe the lecturers' professionalism at English Education Department in academic year 2011/2012. This was a descriptive research with a survey method, which was carried out by distributing questionnaires. They were 200 students of English Education Department spreading from semester 1 to semester 7 from ten classes as the samples of the study. They were determined purposively by taking into consideration as to whether the class was taught by the lecturer whom they were assessed.The finding proves that (1) the lecturers' professionalism of English Education Department was assessed good by the students (mean: 3.72), (2) from the four competencies, personality competency reached the highest score (mean: 3.93), followed by social competency (mean: 3.88), professional competency (mean: 3.76), and finally pedagogicalcompetency (mean: 3.31), and (3) compared to other competencies, pedagogical competency was assessed the lowest among others and was classified moderate.
\end{abstract}

Keywords: competency, professionalism

\begin{abstract}
Abstrak: Profil Profesionalisme Dosen Jurusan Pendidikan Bahasa Inggris. Tujuan utama penelitian ini adalah untuk mengkaji profesionalisme staf dosen Jurusan Pendidikan Bahasa Inggris tahun akademik 2011/2012. Penelitian ini merupakan penelitian deskriptif dengan metode survei, yaitu melalui penyebaran angket kepada responden, yakni 200 mahasiswa dari semester 1 sampai dengan semester 7 dari sepuluh kelas, yang ditentukan secara purposif berdasarkan kelas-kelas yang diajar oleh para dosen yang bersangkutan. Hasil penelitian membuktikan bahwa (1) secara umum kompetensi dosen Jurusan Pendidikan Bahasa Inggris adalah baik (rerata: 3,72), (2) dari keempat kompetensi yang dinilai, kompetensi kepribadian mendapatkan capaian tertinggi (rerata 3,93) yang diikuti oleh kompetensi sosial (rerata 3,88), kompetensi profesional (rerata 3,76), dan terakhir kompetensi pedagogik (rerata 3,31), dan (3) dibandingkan dengan kompetensi lainnya, kompetesi pedagogik dinilai paling rendah oleh mahasiswa, dengan kategori cukup.
\end{abstract}

Kata-kata Kunci: profesionalisme, kompetensi

Dalam PP No.19 tahun 2005 tentang Standar Nasional Pendidikan diatur bahwa terdapat delapan Standar Nasional Pendidikan yang perlu diperhatikan dalam mendesain dan melaksanakan kurikulum suatu unit pendidikan, yaitu Standar Isi, Standar Proses, Standar Kompetensi Lulusan, Standar Pendidik dan Tenaga Kependidikan, Standar Sarana dan Prasarana, Standar Pengelolaan, Standar Pembiayaan, dan Standar Penilaian Pendidikan.

Dalam salah satu standar tersebut, standar pendidik dan tenaga kependidikan merupakan salah satu faktor penentu sukses tidaknya proses pembelajaran. Dengan demikian, pendidik dan tenaga kependidikan sekaligus merupakan subjek dari standar proses, karena yang mempersiapkan dan mengimplementasikan proses pembelajaran adalah mereka. Oleh karena itu pendidik dan tenaga kependidikan memegang peran yang sangat sentral dalam pendidikan. Pendidikan yang bermutu sangat tergantung dari keberadaan guru atau dosen yang bermutu. Guru atau dosen yang bermutu adalah mereka yang melaksanakan pekerjaaannya secara profesional. Sejalan dengan hal ini, Koster (2006) menegaskan pendidikan yang bermutu tergantung pada keberadaan guru 
yang bermutu, yakni guru yang profesional, sejahtera, dan bermartabat. Menurut Surya (2003), guru yang profesional harus menguasai keahlian dalam kemampuan materi keilmuan dan keterampilan metodologi. Guru juga harus memiliki rasa tanggung jawab yang tinggi atas pekerjaannya baik terhadap Tuhan Yang Maha Esa, bangsa dan negara, lembaga dan organisasi profesi. Selain itu, guru juga harus mengembangkan rasa kesejawatan yang tinggi dengan sesama guru.Secara lebih spesifik, Dantes (2006) menekankan bahwa sebagai upaya untuk memiliki sistem pendidikan tinggi yang baik, maka peran dosen tidak bisa dikesampingkan. Dosen adalah pendidik yang memiliki peran strategis dalam pendidikan formal. Tanggung jawab dosen bukan hanya meningkatkan kemampuan kognitif mahasiswa (instructional effect), tetapi juga meningkatkan nilai-nilai kemanusiaan pada mahasiswa (nurturant effect). Sutjipta (dalam Alam, 2012: 2) menegaskan bahwa "selengkap dan sesempurna apa pun kurikulum dan fasilitas yang dimiliki oleh sebuah universitas, tetapi bila para dosennya malas, tidak kreatif, dan menganggap kegiatan mengajar merupakan kegiatan rutinitas yang statik, maka niscaya pendidikan yang berkualitas dapat dicapai". Sudiana (2003) menekankan bahwa dosen yang profesional adalah mereka yang memiliki kinerja yang tinggi yang dapat memuaskan semua pihak yang berkepentingan (stakeholders), yaitu mahasiswa, orang tua, dan masyarakat dalam arti luas termasuk kepuasan diri sendiri. Dantes (2011) menambahkan bahwa guru (dosen) sebagai pendidik profesional harus mampu menjiwai dan mentransformasikan berbagai nilai-nilai kehidupan baik yang menyangkut hard skill maupun soft skill pada kehidupan dan pertumbuhan kehidupan peserta didik. Dengan demikian, mereka akan mampu menyelenggarakan dan menerjadikan proses pembelajaran yang bermakna. Itu berarti peran guru atau dosen sangat penting dalam ikut memberdayakan peserta didik berkembang menjadi manusia yang berkualitas, sehingga mampu dan proaktif menjawab tantangan zaman yang selalu berubah.

Agar dapat menjadi guru atau dosen yang profesional, maka ada sejumlah kompetensi yang harus dikuasai. Arikunto (2002) menyebutkan tiga kompetensi dasar yang harus dimiliki guru, yaitu kompetensi personal, kompetensi sosial, dan kompetensi profesional. Kompetensi personal berhubungan dengan kemampuan guru untuk memiliki sikap kepribadian yang baik dan terpuji sehingga layak menjadi teladan dan panutan bagi siswanya. Kompetensi sosial berhubungan dengan partisipasi sosial guru dalam kehidupan sehari-hari di masyarakat, baik di tempat kerja dan di tempat tinggalnya, dan kompetensi profesional adalah kemampuan yang berfokus pada pelaksanaan proses belajar mengajar dan dengan hasil belajar siswa. Sudiana (2003) menjelaskan 4 kompetensi yang harus dimiliki oleh dosen, yaitu kompetensi bidang studi, kompetensi pemahaman tentang peserta didik, kompetensi pembelajaran yang mendidik, dan kompetensi pengembangan kepribadian dan keprofesionalan. Sementara, Dantes (2009) dan Santyasa (2011) menyebutkan empat kompetensi yang harus dikuasai oleh guru atau dosen yaitu kompetensi pedagogi, kompetensi profesional, kompetensi sosial, dan kompetensi personal. Kompetensi pedagogi berhubungan dengan kemampuan dalam mempersiapkan dan melaksanakan pembelajaran, seperti memahami karakteristik peserta didik dan gaya belajarnya, mengembangkan perangkat pembelajaran, mengembangkan strategi belajar, mengelola pembelajaran, mengevaluasi hasil belajar, menggunakan teknologi dalam pembelajaran, dan memberikan layanan bimbingan, kompetensi profesional menyangkut kemampuan dalam bidang studi yang ditekuni, termasuk kompetensi keterampilan dan pengembangan dan implementasi pengetahuan, sementara kompetensi sosial berhubungan dengan kemampuan berinteraksi dengan lingkungan yang multikultural, berinteraksi dengan efektif dan tata cara yang sopan, dan adaptif dengan berbagai kelas sosial di masyarakat, terbuka dan menghargai pendapat serta kritik orang lain. Kompetensi kepribadian terkait dengan kemampuan untuk bersikap dan berperilaku sesuai dengan norma dan agama, aturan dan sosial budaya di Indonesia, sebagai individu yang hormat, jujur, adil, berkarisma, dan memiliki integritas, loyal terhadap institusi, bertanggung jawab, dan memiliki etos kerja yang tinggi, menjunjung etika profesi, kreatif, adaptif, inovatif, dan produktif, dan menunjukkan kepemimpinan yang visioner.

Dapat disimpulkan, bahwa sebagai agen pendidikan yang profesional, terdapat empat kompetensi utama yang harus dikuasai oleh dosen, antara lain kompetensi pedagogik, kompetensi profesional, kompetensi sosial, dan kompetensi kepribadian.

Penelitian terkait dengan profesionalisme dosen khususnya di Jurusan Pendidikan Bahasa Inggris belum pernah dilakukan sebelumnya, maka fokus dari penelitian ini adalah untuk meng- 
identifikasi profil profesionalisme dosen Jurusan Pendidikan Bahasa Inggris tahun akademik 2011/2012, yang dikaji dari empat kompetensi yang telah diuraikan di atas.

Gilley dan Eggland (dalam Karsidi, 2011) mendefinisikan profesi sebagai bidang usaha manusia berdasarkan pengetahuan, yakni keahlian dan pengalaman pelakunya diperlukan oleh masyarakat. Definisi ini meliputi aspek yaitu: (a) Ilmu pengetahuan tertentu, (b) Aplikasi kemampuan/kecakapan, dan (c) Berkaitan dengan kepentingan umum. Lebih jauh dikatakan bahwa pengertian profesional dapat didekati dengan empat prespektif pendekatan yaitu orientasi filosofis, perkembangan, karakteristik, dan non tradisional. Ada tiga pendekatan dalam orientasi filosofi, yaitu pertama lambang keprofesionalan adalah adanya sertifikat, lisensi, dan akreditasi. Pendekatan kedua yang digunakan untuk tingkat keprofesionalan adalah pendekatan sikap individu, yaitu pengembangan sikap individual, kebebasan personal, pelayanan umum dan aturan yang bersifat pribadi. Yang penting bahwa layanan individu pemegang profesi diakui oleh dan bermanfaat bagi penggunanya. Pendekatan ketiga: electic, yaitu pendekatan yang menggunakan prosedur, teknik, metode dan konsep dari berbagai sumber, sistem, dan pemikiran akademis. Proses profesionalisasi dianggap merupakan kesatuan dari kemampuan, hasil kesepakatan dan standar tertentu. Pendekatan ini berpandangan bahwa pandangan individu tidak akan lebih baik dari pandangan kolektif yang disepakati bersama. Sertifikasi profesi memang diperlukan, tetapi tergantung pada tuntutan penggunanya.

Perspektif yang kedua, yaitu oreintasi perkembangan. Orientasi perkembangan menekankan pada enam langkah pengembangan profesionalisasi, yaitu: (a) Dimulai dari adanya asosiasi informal individu-individu yang memiliki minat terhadap profesi, (b) Identifikasi dan adopsi pengetahuan tertentu, (c) Para praktisi biasanya lalu terorganisasi secara formal pada suatu lembaga, (d) Penyepakatan adanya persyaratan profesi berdasarkan pengalaman atau kualifikasi tertentu, (e) Penetuan kode etik, dam (f) Revisi persyaratan berdasarkan kualifikasi tertentu (termasuk syarat akademis) dan pengalaman di lapangan.

Perspektif profesional ketiga dilihat dari orientasi karakteristik. Profesionalisasi juga dapat ditinjau dari karakteristik profesi/pekerjaan. Ada delapan karakteristik pengembangan profesionalisasi, satu dengan yang lain saling terkait: (a) Kode etik, (b) Pengetahuan yang terorganisir, (c) Keahlian dan kompetensi yang bersifat khusus, (d) Tingkat pendidikan minimal yang dipersyaratkan, (e) Sertifikat keahlian, (f) Proses tertentu sebelum memangku profesi untuk bisa memangku tugas dan tanggung jawab, (g) Kesempatan untuk penyebarluasan dan pertukaran ide di antara anggota profesi, (h) Adanya tindakan disiplin dan batasan tertentu jika terjadi malpraktek oleh anggota profesi.

Orientasi keempat adalah perspektif nontradisional yang menyatakan bahwa seseorang dengan bidang ilmu tertentu diharapkan mampu melihat dan merumuskan karakteristik yang unik dan kebutuhan dari sebuah profesi. Oleh karena itu perlu dilakukan identifikasi elemen-elemen penting untuk sebuah profesi, misalnya termasuk pentingnya sertifikasi profesional dan perlunya standarisasi profesi untuk menguji kelayakannya dengan kebutuhan lapangan.

Mengacu pada ketentuan umum, yaitu UU No.14 Tahun 2005 (Dantes, 2012), profesi adalah pekerjaan atau kegiatan yang dilakukan oleh seseorang dan menjadi sumber penghasilan kehidupan yang memerlukan keahlian, kemahiran atau kecakapan yang memenuhi standar mutu atau norma tertentu serta memerlukan pendidikan profesi.

Dengan demikian, dapat dikatakan bahwa menjadi guru adalah sebuah profesi atau pekerjaan yang memberikan penghasilan yang membutuhkan pengetahuan, keterampilan, keahlian, dan pengalaman yang memenuhi standar tertentu. Semua komponen yang dibutuhkan untuk menjadi guru didapatkan pada lembaga formal, yaitu institusi yang khusus memberikan pendidikan profesi, yang dapat dilihat dari empat perspektif umum, yaitu orientasi filosofis, perkembangan bertahap, karakteristik, dan nontradisional.

Lebih jauh, Dantes (2012) mengemukakan bahwa kompetensi merupakan seperangkat pengetahuan sikap, keterampilan dan perilaku yang harus dimiliki, dihayati dan dikuasai oleh guru dalam melakukan tugas keprofesionalannya, sedangkan profesional adalah pekerjaan atau kegiatan yang dilakukan oleh seseorang dan menjadi sumber penghasilan kehidupan yang memerlukan keahlian, kemahiran atau kecakapan yang memenuhi standar mutu atau norma tertentu serta memerlukan pendidikan profesi (Ketentuan Umum UU No.14 Tahun 2005). Ketentuan di atas secara eksplisit menyiratkan bahwa profesi guru atau dosen terkait dengan konteks layanan ahli dalam 
bidang keguruan-kependidikan, karena terapan layanan ahli kependidikan itu selalu berlandaskan penguasaan akademik yang solid. Pendidik profesionalharus mampu menjiwai dan mentransformasikan berbagai nilai kehidupan baik yang menyangkut hard skill maupun soft skill pada kehidupan dan pertumbuhan peserta didik. Guru hendaknya mampu menguasai pilar-pilar pendidikan dan pembelajaran (learning to know, learning to do, learning to be, learning to live together, dan learning to live sustainably), sehingga guru dapat menerjadikan proses pembelajaran yang bermakna dan peserta didik menjadi pribadi-pribadi yang utuh yang menguasai ilmu pengethuan dan teknologi, menyadari hak dan kewajiban, dapat melangsungkan kehidupannya, dan melestarikan lingkungan sebagai tempat kehidupannya.

Walker (dalam Yuwono\& Harbon, 201: 148) menjelaskan bahwa guru Bahasa Inggris disebut profesional bila mereka menguasai tiga hal utama, yaitu (1) memiliki kualifikasi pendidikan, (2) memiliki pengetahuan yang baik terhadap bidang studi yang diajarkan, dan (3) menjadi praktisi yang cakap di dalam kelas. Dapat dikatakan bahwa konsep Walker di atas lebih menekankan pada aspek hard skill, yaitu kompetensi pengetahuan dan keterampilan yang harus dimiliki oleh guru bahasa Inggris yang menyebabkan yang bersangkutan mendapatkan kualifikasi atau sertifikat profesi. Sementara itu, Dantes (2012) mendeskripsikan bahwa guru yang utuh adalah guru yang dilihat dari tiga perspektif, yaitu otak, tubuh, dan hati. Dilihat dari otak, guru yang profesional adalah seorang ahli di bidang yang diajarkan, dilihat dari tubuh, guru yang profesional memiliki penampilan sebagi seorang guru yang menjadi teladan, sedangkan hati mengacu pada ketulusan hati dalam memberikan pelayanan pendidikan, sehingga guru tersebut menjadi guru di hati peserta didik. Sejalan dengan Walker (dalam Yuwono dan Harbon, 2011), Dantes (2012) menambahkan bahwa sebagai prasyarat dari praktisi yang cakap, seorang guru seharusnya menguasai karakteristik peserta didik yang diampu dan dilayani secara mendalam dengan berbagai variasi karakter dan cara pendekatannya, menguasai bidang ilmu sumber (bahan ajar) dari segi disciplinary content maupun pedagogical content, menguasai pendekatan pembelajaran yang mendidik dan memandirikan baik menyangkut perancangan, maupun implementasinya, serta mengembangkan kemampuan profesional secara berkelanjutan. Penguasaan dimensi-dimensi konsep akademik yang berhubungan dengan layanan ahli keguruan-kependidikan tersebut serta pengalaman mengaplikasikan dalam profesinya sebagai guru, akan menimbulkan secara berkelanjutan nurturant effects pada kemampuan sosial dan kemampuan personal yang pada gilirannya akan berkontribusi pada kepribadian guru secara makro.

Dengan demikian, dapat disimpulkan bahwa sebagai pendidik yang profesional, dosen wajib menguasai bidang studi yang diajarkan (disciplinary content) dan berbagai pengetahuan terkait dengan pendekatan pembelajaran (pedagogical content), yang secara berkelanjutan hendaknya dikembangkan sesuai dengan perkembangan IPTEK terkini. Penguasaan kedua bidang ini akan berdampak pada nurturant effect, yakni kompetensi personal dan sosial, yang mendukung kompetensi profesional dan kompetensi pedagogik.

Berdasarkan UU No. 14 tahun 2005 dan PP No. 19 tahun 2005 bahwa kompetensi yang harus dimiliki oleh seorang dosen yang profesional meliputi kompetensi profesional, kompetensi pedagogik, kompetensi kepribadian, dan kompetensi sosial. Adapun aspek-aspek yang dinilai pada setiap kompetensi bagi para dosen di Undiskha adalah sebagai berikut.

Untuk kompetensi pedagogik, aspek-aspek yang dinilai adalah (1) kesiapan memberikan kuliah dan/atau praktikum, (2) keteraturan dan ketertiban penyelenggaraan perkuliahan, (3) kemampuan menghidupkan suasana kelas, (4) kejelasan penyampaian materi dan jawaban terhadap pertanyaan di kelas, (5) pemanfaatan media dan teknologi pembelajaran, (6) keanekaragaman cara pengukuran hasil belajar, (7) pemberian umpan balik terhadap tugas, (8) kesesuaian materi ujian dan/atau tugas mata kuliah, dan (9) kesesuaian nilai yang diberikan dengan hasil belajar.

Untuk kompetensi profesional, aspek-aspek yang dinilai adalah (1) kemampuan menjelaskan pokok bahasan/topik secara tepat, (2) kemampuan memberi contoh relevan dari konsep yang diajarkan, (3) kemampuan menjelaskan keterkaitan bidan/topik yang diajarkan dengan bidang/topik lain, (4) kemampuan menjelaskan keterkaitan bidang/topik yang diajarkan dengan konteks kehidupan, (5) penguasaan akan isu-isu mutakhir dalam bidang yang diajarkan, (6) penggunaan hasil-hasil penelitian untuk meningkatkan kualitas perkuliahan, (7) pelibatan mahasiswa dalam penelitian/kajian dan/atau pengembangan rekayasa/desain yang dilakukan dosen, dan 
(8) kemampuan menggunakan beragam teknologi komunikasi.

Aspek-aspek yang dinilai dalam kompetensi kepribadian adalah (1) kewibawaan sebagai pribadi dosen, (2) kearifan dalam mengambil keputusan, (3) menjadi contoh dalam bersikap dan berperilaku, (4) satunya kata dan perbuatan, (5) kemampuan mengendalikan diri dalam berbagai situasi kondisi, dan (6) adil dalam memperlakukan mahasiswa.

Dalam kompetensi sosial, aspek-aspek yang dinilai adalah (1) kemampuan menyampaikan pendapat, (2) kemampuan menerima kritik, saran, dan pendapat orang lain, (3) mengenal dengan baik mahasiswa yang mengikuti kuliahnya, (4) mudah bergaul di kalangan sejawat, karyawan, dan mahasiswa, dan (5) toleransi terhadap keberagaman mahasiswa.

Menurut Mahmud (dalam Sudiana, 2003), kualitas profesional dosen dilaporkan masih rendah. Selanjutnya, penelitian yang dilakukan Dardjowidjojo yang dilakukan pada tahun 2000 terkait dengan kondisi praktik pembelajaran Bahasa Inggris di Indonesia khususnya di Jawa (dalam Yuwono \& Harbon, 2010) menemukan bahwa guru-guru Bahasa Inggris tidak menguasai bahasa yang mereka ajarkan. Oleh karena Jawa merupakan pulau terpenting dan paling maju di antara pulau-pulau lain di Indonesia, maka dapat dibayangkan kalau di daerah lain di luar Jawa mengalami kondisi yang sama. Dalam berbagai kasus, dinyatakan bahwa guru-guru bahasa Inggris di Indonesia sangat tergantung pada buku teks dan kurikulum, tanpa memiliki pemahaman utuh terhadap filosofi yang mendasari materi dan metode mengajar, sehingga banyak guru mengandalkan bukuteks baru dengan sikap metode lama. Dalam penelitian yang dilakukan tahun 2007 kepada 46 guru-guru bahasa Inggris di berbagai sekolah menengah baik negeri maupun swasta di Salatiga melalui wawancara, Yuwono dan Harbon (2010) melaporkan dua di antara lima area profesionalisme yang dikaji, yaitu motif memasuki profesi guru dan penghargaan. Dari segi motif memasuki profesi guru, hasil penelitian melaporkan beberapa motif menjadi guru, antara lain niat yang tulus menjadi guru, tugas religius, kesulitan finansial, kecintaan terhadap bahasa Inggris, peran perempuan, dan kegagalan memasuki profesi lainnya. Sementara dilihat dari penghargaan, secara umum semua guru mengakui bahwa menjadi guru di Indonesia tidak mendapat gaji yang pantas. Mereka menyatakan bahwa profesi mengajar dan profesionalisme mereka belum diberi- kan penghargaan yang semestinya, walaupun mereka telah bekerja keras untuk memenuhi tuntutan orangtua dan masyarakat. Namun demikian, terdapat beberapa guru yang menegaskan bahwa penghargaan finansial bukan merupakan isu utama bagi guru. Tanpa memandang penghargaan, para guru menegaskan bahwa mereka harus tetap profesional. Bagi beberapa guru, penghargaan finasial itu relatif. Gaji cukup bila seseorang berpikir cukup, dan tidak cukup bila seseorang tidak pernah puas. Bahkan ada guru yang berpendapat bahwa penghargaan finansial yang lebih tinggi tidak menjamin profesionalisme seseorang. Lebih jauh dilaporkan bahwa dengan rendahnya gaji yang didapatkan guru, terdapat fenomena umum bahwa guru melakukan pekerjaan kedua. Lebih dari setengah jumlah guru yang diwawancarai mengakui mereka melakukan pekerjaan tambahan, yaitu memberikan les atau tutorial privat di luar jam sekolah untuk siswa dari sekolah-sekolah lainnya.

Berdasarkan hasil penelitian di atas, profesionalisme dosen di Jurusan Pendidikan Bahasa Inggris perlu diteliti untuk mengetahui bagaimana sesungguhnya profil kompetensi mereka yang dari segi penghargaan sudah mendapatkan tunjangan sertifikasi dosen sejak tahun 2006.

Penelitian terkait dengan persepsi mahasiswa terhadap dosen dilakukan oleh Nurchayati (2012) yang dilihat dari tiga konsep utama yaitu keahlian (skill), pengetahuan (knowledge) dan karakter (character), dan hasil analisis deskriptif membuktikan bahwa mahasiswa menyatakan bahwa keahlian, pengetahuan, dan karakter dosen akutansi di Fakultas Ekonomi Universitas 17 Agustus 1945 Semarang tinggi. Sementara uji inferensial dengan Regresi Linear Berganda membuktikan bahwa keahlian dan pengetahuan dosen berpengaruh positif terhadap IPK mahasiswa, tetapi tidak pada karakter. Berdasarkan penelitian ini, profil dosen Jurusan Pendidikan Bahasa Inggris dinilai oleh mahasiswa dilihat dari empat kompetensi, yakni profesional, pedagogik, sosial, dan kepribadian.Profesional merujuk pada penguasaan pengetahuan yang diampu (knowledge), pedagogik mengacu pada keahlian (skill) dan sosial dan kepribadian menyangkut tentang karakter (character).

\section{METODE}

Pendekatan dari penelitian ini adalah pendekatan kuantitaif dan rancangan penelitiannya adalah penelitian deskriptif. Peneliti mendes- 
kripsikan secara apa adanya temuan penelitian yang bersumber dari instrumen utama berupa angket yang disebarkan kepada mahasiswa Jurusan Pendidikan Bahasa Inggris tahun akademik 2011/2012. Populasi penelitian adalah semua mahasiswa Jurusan Pendidikan Bahasa Inggris pada tahun 2011/2012 yang berjumlah 489 dan sampel penelitian adalah 200 mahasiswa dari 10 kelas yang ditentukan secara purposif berdasarkan kelas yang diajar oleh dosen yang bersangkutan. Objek dari penelitian ini adalah profesionalisme dosen Jurusan Pendidikan Bahasa Inggris pada tahun akademik 2011/2012, yang dilihat dari empat kompetensi, yaitu kompetensi profesional, kompetensi pedagogik, kompetensi kepribadian, dan kompetensi sosial, yang melibatkan 25 orang dosen. Instrumen utama dari penelitian ini adalah angket yang disebarkan kepada mahasiswa yang diajar oleh dosen yang bersangkutan sesuai dengan mata kuliah yang muncul pada semester tersebut.

Teknik pengumpulan data dari penelitian ini mengikuti langkah-langkah,yaitu (1) para korti dari semester satu sampai dengan semester tujuh dikumpulkan dan diberikan pengarahan agar me-reka memberikan penilaiannya secara objektif ketika mengisi angket, (2) para korti tersebut kemudian diberikan masing-masing sejumlah 20 angket untuk menilai satu orang dosen, dan (3) angket yang sudah diisi segera dikembalikan kepada peneliti untuk ditabulasikan dan dianalisis.

Teknik analisis yang dilakukan adalah mencari nilai rerata (mean score) pada masingmasing kompetensi, yaitu kompetensi pedagogik, profesional, kepribadian, dan sosial. Setelah itu dicari nilai rerata kompetensi dosen secara keseluruhan maupun per kompetensi dari 4 kompetensi. Di samping itu, analisis data juga dilakukan dengan mencari persentase jumlah dosen yang mendapatkan skor tertentu berdasarkan kategorinya. Selain keempat kompetensi yang dianalisis, masukan yang diberikan oleh mahasiswa pada pernyataan terbuka juga dilaporkan.

\section{HASIL DAN PEMBAHASAN}

\section{Hasil}

Hasil dari evaluasi dosen yang dinilai oleh mahasiswa Pendidikan Bahasa Inggris dapat dilihat pada Tabel 1.

Tabel 1. Hasi Evaluasi Dosen

\begin{tabular}{|c|c|c|c|c|c|}
\hline \multirow{2}{*}{$\begin{array}{c}\text { No } \\
\text { Item }\end{array}$} & \multicolumn{4}{|c|}{ Kompetensi yang Dinilai } & \multirow{2}{*}{ Rerata } \\
\hline & Pedagogik & Profesional & Kepribadian & Sosial & \\
\hline 1 & 3,42 & 3,34 & 4,00 & 3,32 & 3,52 \\
\hline 2 & 4,02 & 4,09 & 4,12 & 4,02 & 4,06 \\
\hline 3 & 4,22 & 4,41 & 4,48 & 4,37 & 4,37 \\
\hline 4 & 4,42 & 4,23 & 4,03 & 4,21 & 4,22 \\
\hline 5 & 4,21 & 4,05 & 4,48 & 4,21 & 4,24 \\
\hline 6 & 3,05 & 3,12 & 2,34 & 2,73 & 2,81 \\
\hline 7 & 3,16 & 2,55 & 3,51 & 2,92 & 3,04 \\
\hline 8 & 3,48 & 3,30 & 4,11 & 3,42 & 3,58 \\
\hline 9 & 2,04 & 2,08 & 2,31 & 2,43 & 2,22 \\
\hline 10 & 3,97 & 3,69 & 4,34 & 3,97 & 3,99 \\
\hline 11 & 3,41 & 3,83 & 3,60 & 3,50 & 3,59 \\
\hline 12 & 4,71 & 4,44 & 4,57 & 4,68 & 4,60 \\
\hline 13 & 4,02 & 4,07 & 4,05 & 3,95 & 4,02 \\
\hline 14 & 3,87 & 3,89 & 4,06 & 4,29 & 4,03 \\
\hline 15 & 3,89 & 4,11 & 3,96 & 4,16 & 4,03 \\
\hline 16 & 3,95 & 4,01 & 3,89 & 4,05 & 3,98 \\
\hline 17 & 4,11 & 3,85 & 4,26 & 4,12 & 4,09 \\
\hline 18 & 3,97 & 3,97 & 3,85 & 4,06 & 3,96 \\
\hline 19 & 3,49 & 3,41 & 3,58 & 3,71 & 3,55 \\
\hline 20 & 4,19 & 4,03 & 4,36 & 4,21 & 4,20 \\
\hline 21 & 4,06 & 3,89 & 4,26 & 4,30 & 4,13 \\
\hline 22 & 3,96 & 3,85 & 3,99 & 4,06 & 3,97 \\
\hline 23 & 4,06 & 4,28 & 4,30 & 4,45 & 4,27 \\
\hline Total & 76,02 & 86,49 & 90,45 & 89,13 & \\
\hline Rerata & $\mathbf{3 , 3 1}$ & 3,76 & 3,93 & $\mathbf{3 , 8 8}$ & \\
\hline
\end{tabular}




\section{Jumlah Rerata Keempat Kompetensi}

Rerata Total dari Keempat Kompetensi

Dari Tabel 1 diatas, dapat dilihat bahwa jumlah rerata total dari keempat kompetensi dosen Pendidikan Bahasa Inggris mencapai angka 3,72 . Nilai dengan rata-rata terkecil 2,22 dan rata-rata tertinggi 4,60. Untuk nilai kategori $3>\mathrm{N}>2$ (nilai lebih tinggi dari 2 dan lebih kecil dari 3) ada sebanyak 2 buah. Sedangkan untuk kategori $4>\mathrm{N}>3$ (nilai lebih tinggi dari 3 dan lebih kecil dari 4) terdapat 9 buah nilai dan untuk kategori $\mathrm{N}>4$ (nilai lebih besar dari 4) ada sebanyak 12 nilai. Setelah mendapatkan hasil, didapatlah jumlah keseluruhan per kompetensi yang terletak pada baris 'Total'.

Secara keseluruhan, Tabel 1 menunjukkan bahwa kompetensi Dosen Bahasa Inggris dapat digolongkan baik dengan capaian rerata 3,72. Bila dilihat 4 kompetensi dari masing-masing dosen yang dievaluasi oleh mahasiswa, terdapat hanya 1 dosen $(4,35 \%)$ yang memiliki nilai rerata kompetensi 5 (kategori sangat baik), 19 dosen $(82,61 \%)$ mencapai nilai rerata kompetensi 4 (kategori baik). Namun demikian, 2 dosen $(8,69 \%)$ mencapai nilai rerata kompetensi 3 (kategori cukup) dan 1 dosen $(4,35 \%)$ mencapai nilai rerata kompetensi 2 (kategori kurang).

\section{Pembahasan}

Berdasarkan hasil penelitian yang telah dipaparkan pada Tabel 1, dapat dilihat bahwa kompetensi dosen secara umum terkategori baik (rerata 3,72) dari empat kompetensi. Bukti ini sekaligus menolak pernyataan dari Mahmud (dalam Sudiana, 2003) yang menegaskan kualitas profesional dosen masih rendah. Penilaian yang diberikan oleh mahasiswa membuktikan bahwa dosen Jurusan Pendidikan Bahasa Inggris pada tahun 2012 memiliki kriteria kompetensi yang baik. Hasil penelitian ini sekaligus mendukung Nurchayati (2012) bahwa dosen hendaknya memiliki keahlian (skill), pengetahuan (knowledge), dan karakter yang memadai sebagai agen pembelajaran yang dapat berpengaruh terhadap hasil belajar mahasiswa.

Namun demikian, jika dilihat per kompetensi, penilaian mahasiswa membuktikan bahwa di antara 4 kompetensi yang dinilai, kompetensi pedagogik dan profesional lebih rendah dibandingkan sosial dan kepribadian. Kompetensi kepribadian memiliki nilai rerata yang paling tinggi, yaitu 3,93. Data ini membuktikan bahwa mahasiswa menilai baik kepribadian semua dosen Jurusan Pendidikan Bahasa Inggris. Adapun as-
14,87

3,72

pek penilaian yang mencakup kompetensi kepribadian adalah kewibawaan sebagai dosen, kearifan dalam mengambil keputusan, menjadi contoh dalam bersikap dan berperilaku, satunya kata dan perbuatan, kemampuan mengendalikan diri dalam berbagai situasi dan kondisi, adil dalam memperlakukan mahasiswa. Mengacu pada Dantes (2007), kompetensi kepribadian hendaknya menjadi landasan bagi tiga kompetensi lainnya, yaitu kompetensi sosial, kompetensi profesional, dan kompetensi pedagogik. Dengan demikian, penelitian ini mendukung teori dari Dantes (2007) dan Santyasa (2011) bahwa terbukti kompetensi kepribadian dosen Bahasa Inggris yang dinilai baik oleh mahasiswa menjadi fondasi bagi tiga kompetensi lainnya.

Demikian pula dilihat dari kompetensi sosial (rerata 3,88), mahasiswa menilai baik kemampuan semua dosen Bahasa Inggris dalam berinteraksi dengan mahasiswa maupun di antara dosenmelalui 5 aspek penilaian, yaitu kemampuan menyampaikan pendapat, kemampuan menerima kritik, saran dan pendapat orang lain, mengenal dengan baik mahasiswa yang mengikuti kuliahnya, mudah bergaul di kalangan sejawat, karyawan, mahasiswa, dan toleransi terhadap keberagaman mahasiswa. Penilaian kompetensi sosial pada dosen merupakan aspek cerminan dari ketiga kompetensi lainnya sekaligus merupakan prasyarat dari praktisi yang cakap sebagaimana diungkapkan oleh Dantes (2012) dan Santyasa (2011) bahwa seorang guru seharusnya menguasai karakteristik peserta didik yang diampu dan dilayani secara mendalam dengan berbagai variasi karakter dan cara pendekatannya. Dengan pemahaman terhadap berbagai keberagaman peserta didik, dosen dapat memberikan pelayanan yang memadai kepada mereka. Di samping itu, kemampuan dosen bergaul dengan teman sejawat, karyawan, dan mahasiswa mencerminkan bahwa dosen adalah makhluk yang bergaul, yang tidak dapat hidup tanpa kehadiran orang lain. Tirtarahardja dan Sulo (2005) menegaskan bahwa seseorang hanya dapat mengembangkan individualitasnya dalam pergaulan sosial. Hanya dengan berinteraksi dengan sesamanya (memberi atau menerima), seseorang dapat menyadari dan menghayati kemanusiaannya. Konsep memberi dan menerima terkait dengan kemampuan menyampaikan pendapat, menerima kritik dan saran dalam pengembangan kompetensinya sebagai dosen yang cakap. Mengutip seorang filsuf terke- 
nal Immanuel Kant (dalam Tirtarahardja \& Sulo, 2005: 19) bahwa manusia hanya menjadi manusia bila berada di antara manusia. Dengan demikian, dapat disarikan bahwa dosen yang cakap adalah dosen yang selalu menyadari keberadaannya bersama orang lain, yang mampu mengenali semua peserta didik yang diajar dengan berbagai keberagamannya, mudah bergaul dengan teman sejawat, dan diterima oleh semua karyawan dalam menjalankan profesinya.

Selanjutnya, kompetensi profesional merupakan kompetensi yang paling penting yang harus dimiliki oleh dosen mencapai nilai rerata 3,76 dikategorikan baik. Kompetensi ini dinilai oleh mahasiswa Jurusan Pendidikan Bahasa Inggris melalui kemampuan dosen dalam menjelaskan pokok bahasan/topik secara tepat, kemampuan dosen dalam memberi contoh relevan dari konsep yang diajarkan, kemampuan dosen dalam menjelaskan keterkaitan bidang/topik yang diajarkan dengan bidang/topik lain, kemampuan dosen menjelaskan keterkaitan bidang/topik yang diajarkan dengan konteks kehidupan, penguasaan yang dimiliki dosen atas isu-isu mutakhir dalam bidang yang diajarkan, penggunaan hasil-hasil penelitian untuk meningkatkan kualitas perkuliahan oleh dosen, pelibatan mahasiswa dalam penelitian atau kajian dan atau pengembangan rekayasa/desain yang dilakukan dosen, kemampuan dosen dalam menggunakan beragam teknologi komunikasi. Dilihat dari aspek penilaian tersebut, dapat dikatakan bahwa kompetensi profesional adalah aspek penting dan utama yang harus dimiliki seorang pengajar, karena hal utama yang harus dapat dilakukan oleh seorang pengajar adalah menyampaikan pengetahuan kepada anak didiknya. Kompetensi ini harus memenuhi standar mutu, sehingga pembelajaran yang dilakukan oleh dosen terkait dalam bidang yang diampu hendaknya juga memenuhi standar mutu yang dipersyaratkan oleh kurikulum dan silabus. Standar mutu yang dimaksudkan sejalan dengan Walker (dalam Yuwono \& Harbon, 2011: 148) bahwa terdapat tiga hal mendasar yang menjadi prasyarat pengajar yang profesional, yaitu memiliki kualifikasi pendidikan, memiliki pengetahuan yang baik terhadap bidang studi yang diajarkan, dan menjadi praktisi yang cakap di dalam kelas. Dapat disimpulkan bahwa dosen Jurusan Pendidikan Bahasa Inggris telah memenuhi persyaratan kualitas yang baik dilihat dari segi kompetensi profesional. Dibandingkan dengan penelitian yang dilakukan Dardjowidjojo pada tahun 2000 (dalam Harbon \& Yuwono, 2011) dapat dikemu- kakan bahwa kompetensi profesional para dosen Jurusan Pendidikan Bahasa Inggris berbeda dengan para guru di Jawa yang dibuktikan memiliki penguasaan yang rendah terhadap Bahasa Inggris yang diajar, karena para dosen sudah memiliki kompetensi profesional di bidang studi yang diemban dengan baik. Temuan penelitian ini sejalan dengan paparan Surya (2003), yang menegaskan bahwa seorang dosen yang profesional hendaknya memiliki keahlian dalam materi keilmuan dan ketrampilan metodologi dalam bidang yang diampu.

Temuan yang menarik dari penelitian ini adalah bahwa kompetensi pedagogik dinilai paling rendah oleh mahasiswa (rerata 3,31) yang tergolong cukup. Adapun aspek penilaian dari kompetensi pedagogik yaitu; kesiapan dosen dalam memberi perkuliahan atau praktikum, keteraturan dan ketertiban penyelenggaraan perkuliahan oleh dosen, kemampuan dosen dalam menghidupkan suasana kelas, kejelasan penyampaian materi dan jawaban terhadap pertanyaan dikelas oleh dosen, pemanfaatan media dan teknologi pembelajaran oleh dosen, keanekaragaman cara pengukuran hasil belajar yang dilakukan dosen, pemberian umpan balik terhadap tugas, kesesuaian materi ujian dan/atau tugas dengan tujuan mata kuliah, dan kesesuaian nilai yang diberikan dengan hasil belajar oleh dosen. Kompetensi ini juga merupakan kompetensi penting selain kompetensi profesional karena kompetensi ini melingkupi bagaimana seorang pengajar mampu menyiapkan dan menyampaikan materi secara benar serta mampu melayani segala pertanyaan dari peserta didik.

Penilaian mahasiswa Jurusan Pendidikan Bahasa Inggris terhadap kompetensi pedagogik paling rendah dibandingkan dengan yang lain (rerata 3,31) cukup beralasan. Ada beberapa kritik dan saran yang mereka tuliskan pada pertanyaan terbuka pada kuesioner terkait dengan kompetensi pedagogik. Dalam hal meningkatkan suasana kelas, 18 dosen $(78,26 \%)$ dikomentari oleh mahasiswa masih perlu meningkatkan suasana kelas, karena ada dosen yang terlalu toleran dengan kondisi kelas, kelas dibiarkan saja kurang kondusif, kurang dapat menghidupkan suasana, dan ada ketakutan serta ketegangan dalam belajar. Terkait dengan kesiapan memberi kuliah, 9 dosen $(39,13 \%)$ ditengarai kurang siap memberi kuliah, dengan alasan sering digantikan dengan dosen lain, dosen kurang jelas dalam menjelaskan, sehingga mereka bingung dengan materi yang disampaikan, ada keraguan dalam mene- 
rangkan materi, dan kurang memberikan contoh. Sehubungan dengan keteraturan dan ketertiban dalam penyelenggaraan kuliah, 8 dosen $(34,78 \%)$ dikritik oleh mahasiswa sering mengganti jam pelajaran (make up class), oleh karena kesibukan-kesibukannya. Bahkan ada mahasiswa menuliskan bahwa dia sesungguhnya senang diajar oleh dosen tertentu, tetapi jarang diajar oleh karena berbagai kesibukan terkait tugas-tugas lain. Ada dosen yang juga secara tiba-tiba mengganti jadwal mengajar secara sepihak, sehingga mereka merasa dirugikan. Dalam hal pemanfaatan media, 4 dosen $(17,4 \%)$ dikritik kurang mampu memvariasikan pembelajaran dengan menggunakan media pembelajaran yang lebih inovatif, tetapi terdapat 1 dosen $(4,35 \%)$ dikatakan canggih dalam penggunaan media (moodle) tetapi mahasiswa merasa bingung. Selanjutnya, terdapat 3 dosen $(13,04 \%)$ yang dinyatakan kurang beraneka ragam dalam mengukur hasil belajar mahasiswa, 2 dosen $(8,7 \%)$ dianggap kurang sesuai penilaian yang diberikan terhadap kemampuan mahasiswa, dan 1 dosen $(4,35 \%)$ dinyatakan kurang sesuai penilaian yang diberikan dengan materi yang diajarkan.

Sesungguhnya kompetensi pedagogik adalah kompetensi yang penting terutama terkait dengan bagaimana seorang dosen mempersiapkan dan melaksanakan pembelajaran. Seperti yang diungkapkan oleh Dantes (2009) dan Santyasa (2011), kompetensi pedagogik seperti memahami karakteristik peserta didik dan gaya belajarnya, mengembangkan perangkat pembelajaran, mengembangkan strategi belajar, mengelola pembelajaran, mengevaluasi hasil belajar, menggunakan teknologi dalam pembelajaran, dan memberikan layanan bimbingan merupakan kompetensi utama setelah kompetensi profesional. Hal ini menjadi penting karena tugas seorang dosen adalah untuk membuat pembelajaran berkualitas dan mudah diterima oleh peserta didik, yang akan berpengaruh terhadap hasil belajar mereka. Bila pembelajaran tidak dikemas dan disampaikan dengan baik, maka hasil yang dicapai tidak akan maksimal.

Berdasarkan temuan ini, dapat disimpulkan bahwa dosen Jurusan Pendidikan Bahasa Inggris harus lebih meningkatkan kompetensi pedagogiknya agar mencapai minimal terkategori baik. Begitu pula ketiga kompetensi lainnya yaitu kepribadian, sosial dan profesional yang sudah baik, juga masih perlu ditingkatkan, supaya bisa menjadi sangat baik. Dengan demikian, dosen yang utuh adalah dosen yang bukan hanya ber- kompetensi terkategori baik sebagai individu dengan kepribadiannya, tetapi juga baik secara sosial dalam pergaulannya dengan orang-orang di sekelilingnya, yaitu mahasiswa, teman sejawat, dan karyawan, dan yang utama adalah berkompetensi baik secara profesional dan pedagogik. Dua yang terakhir sangat menentukan seorang dosen dapat dikatakan profesional, karena terkait dengan keahlian dan kemahiran dalam bidang studi yang diemban (disciplinary contents) dan pelaksanaan pembelajaran (pedagogical contents).

\section{SIMPULAN}

Secara umum kompetensi dosen Jurusan Pendidikan Bahasa Inggris pada tahun akademik 2011/2012 terkategori baik. Kompetensi kepribadian dinilai paling tinggi dibandingkan kompetensi-kompetensi lainnya, yang mengindikasikan bahwa sebagai pribadi, dosen Jurusan Pendidikan Bahasa Inggris adalah pribadi-pribadi yang baik yang patut diteladani oleh mahasiswa. Kompetensi sosial juga dinilai baik oleh mahasiswa yang berarti bahwa secara sosial, dosen jurusan pendidikan adalah dosen yang dapat bergaul dan berkomunikasi dengan baik bukan hanya kepada mahasiswa, teman sejawat, tetapi juga karyawan. Kompetensi profesional dinilai baik dan dapat dimaknai bahwa dosen Jurusan Pendidikan Bahasa Inggris memiliki kemahiran dan penguasaan yang baik terhadap bidang studi yang diajarkan (disciplinary contents). Kompetensi pedagogik terkategori cukup. Ada beberapa faktor yang menyebabkan penilaian mahasiswa paling rendah pada kompetensi ini, yaitu kemampuan dalam menghidupkan suasana kelas, kesiapan memberikan perkuliahan, keteraturan dan ketertiban dalam penyelenggaraan perkuliahan, pemanfaatan media/teknologi, keragaman penggunaan cara pengukuran, kesesuaian penilaian, dan kesesuaian materi yang diajar dengan materi ujian.

Sesuai dengan simpulan di atas, hal-hal yang perlu disarankan (1) dosen Jurusan Pendidikan Bahasa Inggris hendaknya dapat meningkatkan kompetensinya sebagai usaha meningkatkan kualitas pembelajaran, (2) kompetensi kepribadian, kompetensi sosial dan kompetensi profesional hendaknya dapat ditingkatkan, (3) kompetensi pedagogik yang dinilai cukup oleh mahasiswa, hendaknya menjadi perhatian khusus semua dosen Jurusan Pendidikan Bahasa Inggris. Dosen hendaknya lebih meningkatkan suasana kelas yang lebih menarik dalam pembelajaran, lebih 
teratur dalam penyelenggaraan kuliah, lebih bervariasi dalam menggunakan media/teknologi pembelajaran, dan lebih sesuai dalam menilai ha-

\section{DAFTAR RUJUKAN}

Alam, H.S. 2012. A Study of Lecturers' Professionalism in STMIK STIKOM Indonesia, Bali. Tesis tidak diterbitkan. Program Studi Pendidikan Bahasa. Singaraja: Universitas Pendidikan Ganesha.

Arikunto, S. 2002. Prosedur Penelitian: Suatu Pendekatan Praktek. Jakarta: Rineka Cipta.

Dantes, N. 2006. Peningkatan Profesionalisme Dosen sebagai Tenaga Akademik. Materi Pelatihan Teknis Fungsional Pengembangan STSI Denpasar yang diselenggarakan tanggal 24 Agustus 2006.

Dantes, N. 2007. Pengantar Pendidikan dan Inovasi Pembelajaran. Singaraja: Program Pasca Sarjana Universitas Pendidikan Ganesha Dantes, N. 2009. Standar Kompetensi Dosen. Singaraja: Universitas Pendidikan Ganesha.

Dantes, N. 2011. Pembinaan Guru Profesional Berbasis Karakter (Suatu Rangkaian Perspektif dan Kebijakan Pendidikan Menghadapi Tantangan Global). Materi Pendidikan dan Latihan Profesi Guru. Singaraja: Universitas Pendidikan Ganesha.

Dantes, N. 2012. Profesi Guru Dalam Kaitannya Dengan Peningkatan Profesionalisme Guru (Refleksi Tentang Struktur Program LPTK). (Online), (http://nyomandantes.wordpress.com/page/2/, diakses tanggal 28 Januari 2012).

Karsidi, R. 2011. Profesionalisme Guru dan Peningkatan Mutu Pendidikan di Era Otonomi Daerah. (Online), (http://www. uns.ac.id/data/0023.pdf, diakses tanggal 19 Desember 2011). sil belajar mahasiswa dengan materi yang diajarkan.

Koster, W. 2006. Memperjuangkan Nasib Guru dan Dosen, Sikap dan Pandangan Seorang Anggota Fraksi PDIP DPR RI dalam Pembentukan dan Pelaksanaan UU Guru dan Dosen. Hak Cipta @ Wayan Koster, November 2006.

Nurchayati.2012. Persepsi Mahasiswa terhadap Profesionalisme Dosen Akutansi Fakultas Ekonomi Universitas 17 Agustus 1945 Semarang. Serat Acitya Jurnal Ilmiah UNTAG Semarang1(1): 1-10.

Peraturan Pemerintah Republik Indonesia No.19 Tahun 2005 tentang Standar Nasional Pendidikan. 2005. Jakarta: Kementrian Pendidikan Nasional.

Rahardja, T.\& Sulo, S.I. La. 2005. Pengantar Pendidikan. Jakarta: PT. Rineka Cipta.

Santyasa, I W. 2011. Dimensi-Dimensi Teoretis Peningkatan Profesionalisme Guru. (Online). (http://staipumajalengka.Files. Wordpress.com/2009/09/dimensiteoritisprofesionalisguru.pdf, diakses 19 Desember 2011).

Sudiana, I N. 2003.Peranan Profesionalisme Tenaga Pengajar (Dosen) terhadap Proses Pembelajaran di Perguruan Tinggi. Jurnal Pendidikan dan Pengajaran IKIP Negeri Singaraja. (Online), 36(4). (http://www. lemlit.undiksha,ac.id/images/img_item/680 .doc, diakses 28 Desember 2015).

Surya, M. 2003. Percikan Perjuangan Guru. Semarang: Aneka Ilmu.

Yuwono, G.I. dan Harbon, L. 2010. English Teacher Professionalism and Professional Development: Some Common Issues in Indonesia. The Asian EFL Journal Quarterly, 12(3): 145-163. 